\title{
Religiosity and lifestyle of professionals from the family health support centers ${ }^{\#}$
}

Religiosidade e estillo de vida de profissionais de um núcleo de apoio à saúde da família

\begin{abstract}
Religiosity is part of the completeness of the human being and can positively influence people's lifestyle. This, in turn, is associated with chronic noncommunicable diseases in Brazil and worldwide. From this context, the objective of this study was to analyze the association between religiosity and lifestyle of health professionals from the Family Health Support Centers (NASF). It is a descriptive, cross-sectional and quantitative study. Convenience sample have been taken, in which 29 professionals answered two questionnaires: Religiosity Index "Duke-Durel" and Lifestyle "Fantastic". It was found with the studied group that the majority were female $(69 \%, \mathrm{n}=20)$ and declared themselves Evangelicals $(79 \%, \mathrm{n}=23)$ with an average age of $31.7(\mathrm{SD}=5.71)$. Participants had good religious involvement $(59 \%$ or more) and the lifestyle is "very good" (total score of 79.4) but are deficient in "physical activity" dimension with an average below normal (2.93, range 0-8). Almost all of them claimed to have received approach on spirituality in academic school, and had involvement in religious cults, considering the religious practice of great importance in their daily, personal and professional life. It was concluded that none of the religious variables was statistically associated with lifestyle dimensions or to their total score. However, there was an association between the variable "church attendance" and "to be or not practitioner" of religion.
\end{abstract}

Keywords: Religion. Spirituality. Lifestyle. Health promotion.

\section{Resumo}

A religiosidade faz parte da integralidade do ser humano e pode influenciar positivamente no estilo de vida das pessoas. Este, por sua vez, está associado às doenças crônicas não transmissíveis no Brasil e no mundo. Partindo desse contexto, o objetivo do presente estudo foi analisar a associação entre religiosidade e estilo de vida de profissionais de saúde de um Núcleo de Apoio à Saúde da Família (NASF). Pesquisa descritiva, de corte transversal e quantitativa. Amostra de conveniência que incluiu 29 profissionais. Aplicou-se dois questionários: Índice de Religiosidade Duke-Durel e Estilo de Vida Fantástico. Constatou-se, no grupo estudado, que a maioria era do sexo feminino (69\%, n=20) e se declarou evangélica $(79 \%, n=23)$ com idade média de 31,7 (dp=5,71). Os participantes possuíam bom envolvimento religioso (59\% ou mais) e o estilo de vida "muito bom" (escore total de 79,4), porém são deficientes na dimensão "atividades físicas", com média abaixo do normal (2,93 com amplitude de 0-8). A maioria declarou ter recebido enfoque sobre espiritualidade na formação acadêmica e afirmou envolvimento em cultos religiosos, considerando a prática da religião de grande relevância em sua vida diária, pessoal e profissional. Conclui-se que, nenhuma das variáveis da religiosidade esteve estatisticamente associada às dimensões do estilo de vida Fantástico bem como ao seu escore total, no entanto houve associação entre a variável "frequência à igreja" e "ser ou não praticante" da religião.

Palavras-chave: Religião. Espiritualidade. Estilo de Vida. Promoção da Saúde.

DOI: $10.15343 / 0104-7809.20164003310318$

\footnotetext{
" Article based on a Master's thesis of the student Evelson Silva, entitled "Association between religiosity and professional lifestyle of a support center for family health in the south of São Paulo - sp" - Adventist University Center of São Paulo - defense: 12.14.2015 (68p).

*UNASP/SP - Centro Universitário Adventista de São Paulo, São Paulo - SP, Brasil. E-mail: evelsons@ig.com.br **UNASP/SP - Centro Universitário Adventista de São Paulo, São Paulo - SP, Brasil. E-mail: ginabdala@gmail.com ***UNASP/SP - Centro Universitário Adventista de São Paulo, São Paulo - SP, Brasil. E-mail: dyrcem@yahoo.com.br The authors declare no conflicts of interest
} 


\section{INTRODUCTION}

Investigations were found in surveys published in the world that show the importance of the relationship between health and Religiosity/Spirituality $(R / S)^{1-2}$. In recent years, studies in Brazilian society show that the issue of $R / S$ is something very meaningful and relevant, increasing in recent publications that have highlighted the importance of these dimensions in the physical and mental health ${ }^{3-5}$.

The results of these research show that Brazilians, in general, find support in the $R / S$ for coping stressing situations ${ }^{6-8}$. The man is a comprehensive, biopsychosocial human being and should be assisted with this comprehensive vision by a health system, which also proposes a comprehensive care, aimed to promote, protect and recover their health ${ }^{9}$.

Unfortunately, the reality today in Brazil is not able to view comprehensive care actions in the Unified Health System (SUS) that can contemplate the humanization, especially in the Family Health Strategy (FHS), through simple actions a willingness to listen, to exchange experiences and share the history of a life with others $^{10}$, either in the host or in clinical care. With this lack of comprehensiveness in health care, the increased prevalence and incidence of disabling chronic diseases and mental health problems are noticed.

To minimize the harm caused by disability from these diseases, it is also necessary to know the lifestyle of the people, so public policy proposals and implement programs can be supported aiming at promoting health. The lifestyle has influenced greatly in the panorama of chronic diseases in Brazil and the world ${ }^{11}$.

The Pan American Health Organization (PAHO) considers health and lifestyle as something vital to be observed by any person, mainly because chronic diseases appear as the main cause of death and disability worldwide, accounting for $59 \%$ of the 56.5 million annual deaths ${ }^{12}$.

On lifestyle, the National Health Agency published reports in 2009 and 2013 concerning Health Promotion and Risk and Diseases Prevention, highlighting the key protective factors such as healthy eating, physical activity and the very quality of life, resulting in a reduction of the lost years and the increase in life expectancy of individuals and populations ${ }^{13,14}$.

In modern science, there are studies about the barriers that need to be overcome by health professionals, as the R/S. In one study, the main barriers identified were: fear of imposing their beliefs $(46.6 \%)$; lack of time $(23.0 \%)$; fear of offending patients $(18.9 \%)$; lack of knowledge (14.9\%); discomfort with the topic (14.2\%); lack of training (10.1\%); other reasons $(9.5 \%)$; "it is not part of my job" (4.7\%); fear that colleagues do not approve it (3.4\%) and "the knowledge of religion is not relevant" $(2.7 \%)$.

In clinical practice, most professionals believe that spirituality influenced the health of their patients, and many of them admitted that they felt like making this approach, but did not consider themselves able to identify a spiritual need nor to provide appropriate assistance ${ }^{15}$.

Considering the importance of $\mathrm{R} / \mathrm{S}$ for comprehensive health care and that religion and lifestyle adopted by these health professionals can influence the management of the needs of the sick person, this study aimed to investigate the association between religiousness and lifestyle of professionals working in a Support Center for Family Health of a Regional Family Health Strategy of the South of São Paulo.

\section{METHODOLOGY}

This is a descriptive, cross-sectional study with a quantitative approach, developed in partnership with the research group Religiosity/ Spirituality in the Comprehensive Health (REIS Group), certified by CNPq. It is part of a larger study entitled "The Perception of the FHP Health Professionals about the Spiritual Assistance to Patients", duly authorized by the Ethics Committee of the Adventist University Center of São Paulo - CEP/UNASPSP (CAAE: 28905914.30000.5377) and by the Ethics Committee of the Municipal Health Secretary of São Paulo - CEP/SMS (CAAE: 28905914.3.3001.0086). 
The sociodemographic data of the professionals collected were age, gender, religion, practicing or not, profession, the school he graduated, working time, if he received spiritual approach on training, if he had training for spiritual assistance and participated in the training.

DUKE-DUREL Religiosity instrument was applied, validated in Brazil. This instrument measures the Organizational Religious Affiliation (ORA, attendance at religious meetings), Non Organizational Religious Affiliation (NORA, frequency of private religious activities) and Intrinsic Religiosity (IR, search internalization and full experience of religiosity) ${ }^{16,17}$. Together, the participants were asked to answer the questionnaire called Fantastic Lifestyle, validated in Brazil in 2008 and 2014. It is an instrument that classifies the lifestyle according to the final score, which can be from zero to one hundred (0-100): excellent (85-100), very good (70-84), good (55-69), regular (35-54) and needs to be improved $(0-34)^{18}$.

In the convenience sample, all NASF

\section{RESULTS}

professionals $(n=46)$ were invited to participate and 29 accepted. Inclusion criteria involved "to be linked" to NASF as a professional of a regional FHS and take part in the study. The exclusion criteria were only those who were absent due to vacation or out for sick leave at the time of data collection between June and September 2015. Data analysis was performed using the statistical program "SPSS" with descriptive results of the religiosity profile and lifestyle.

To meet the objectives of the study, descriptive techniques of exploratory analysis were used as mean, median, standard deviation, absolute and relative frequency and other statistical tests were performed, namely the Mann-Whitney test to evaluate the association between variables with up to two categories and the Spearman correlation coefficient to assess the association between two ordinal variables. All developed hypothesis tests consider a significance of $5 \%$; that is the null hypothesis was rejected when the p-value was less or equal to 0.05 .
In the inclusion of 29 professionals from NASF survey participants, it was found that the majority were female $(69 \%, n=20) ; 79 \%(n=23)$ reported being evangelicals and $86 \%(n=25)$ were religion practitioners, with a predominance of physical therapy professionals $(34 \%, n=10)$, psychology $(17 \%, \mathrm{n}=5)$, occupational therapy $(14 \%, n=4)$ nutrition $(10 \%, n=3)$ and other $(25 \%, n=7)$. The research shows that most of them $(48 \%, n=14)$ have 3-6 years of work and $59 \%(n=17)$ had a spiritual approach to their education and $48 \%(n=14)$ participated in the training provided in this area by the department where they worked (Table 1).

Also in the characteristics of the sample, it was observed that for the quantitative variables, the average age was $31.57(\mathrm{SD}=5.71)$ years and an average of $8.82(\mathrm{SD}=4.67)$ training years.

Regarding the dimensions of the Religiosity Index (Duke-Durel) about the Organizational
Religious Affiliation (ORA), it was found that $65 \%(n=19)$ of the study participants attended services "more than once a week" or even "once a week." Those who practiced their particular religious activities "more than once a day" or "daily" represented 59\% $(n=17)$ of the sample. As for Intrinsic Religiosity (IR), the questionnaire is identified as IR1, IR2, and IR3, meeting the first two response options there was a percentage of $96 \%(n=28)$ of the importance given to religion and the influence of the daily life of respondents (Table 2).

By classifying the Total Fantastic Lifestyle by category $(n=26)$, it was a classification of: $3.8 \% \operatorname{good}(n=1) ; 76.9 \%$ very good $(n=20)$ and $19.2 \%$ excellent $(n=5)$.

When assessing the Fantastic Lifestyle dimensions, it was observed that the average of the "activities" had the lowest value (2.93; range 0-8) about others. It was the one that got 
a value below average (Table 3).

After the analysis of the scores, there was then the association analyses. This stage was started with the association analysis between the variables of the Duke-Durel to seek confirmation if the individual was or was not practicing the religion and spirituality. The results of the test showed a significant association ( $p$-value less than 0.05) with variable ORA and variable researched about being a practitioner of that religion $(p=0.0229)$ (Table 4). None of the Duke-Durel variables were statistically associated with any of the dimensions or the total score of the Fantastic Lifestyle (Table 5).

Table 1 - Characterization of the Professional of the Family Health Care Center $(n=29)$, research participants, according to absolute and relative frequency. São Paulo, 2015.

\begin{tabular}{|c|c|c|c|}
\hline Variables & Category & $\mathbf{N}$ & $\%$ \\
\hline \multirow[t]{2}{*}{ Gender $(n=28)$} & Female & 20 & 71 \\
\hline & Male & 8 & 29 \\
\hline \multirow[t]{6}{*}{ Religion $(n=29)$} & Evangelicals & 23 & 79 \\
\hline & Catholics & 2 & 7 \\
\hline & Agnostic & 1 & 3.5 \\
\hline & Buddhist & 1 & 3.5 \\
\hline & Spiritism & 1 & 3.5 \\
\hline & None & 1 & 3.5 \\
\hline \multirow[t]{2}{*}{ Practicing $(n=29)$} & Yes & 25 & 86 \\
\hline & No & 4 & 14 \\
\hline \multirow[t]{10}{*}{ Profession $(n=30)$} & Social Ass. & 1 & 3 \\
\hline & Dentist & 1 & 3 \\
\hline & Physical Ed. & 1 & 3 \\
\hline & Physiotherapy & 10 & 34 \\
\hline & Audiologist & 2 & 7 \\
\hline & Doctor & 1 & 3 \\
\hline & Nutritionist & 3 & 10 \\
\hline & Psychologist & 5 & 17 \\
\hline & Psychiatrist & 1 & 3 \\
\hline & $\begin{array}{l}\text { Occupational } \\
\text { Therapist }\end{array}$ & 4 & 14 \\
\hline \multirow[t]{2}{*}{ School graduated $(n=29)$} & Public & 7 & 24 \\
\hline & Private & 22 & 76 \\
\hline \multirow[t]{4}{*}{ Working time $(n=29)$} & 0 to 1 years & 4 & 14 \\
\hline & 1,1 to 3 years & 8 & 28 \\
\hline & 3,1 to 6 years & 14 & 48 \\
\hline & $\begin{array}{l}\text { More than } \\
6 \text { years }\end{array}$ & 3 & 10 \\
\hline
\end{tabular}


... Continued - Table 1

\begin{tabular}{llll}
\hline Received spiritual approach $(\mathbf{n = 2 9})$ & Yes & 17 & 59 \\
\hline & No & 12 & 41 \\
\hline Training spirituality $(\mathbf{n = 2 9 )}$ & Yes & 17 & 59 \\
\hline & No & 12 & 41 \\
\hline Participated in the Training $(\mathbf{n = 2 9})$ & Yes & 14 & 48 \\
\hline & No & 15 & 52 \\
\hline
\end{tabular}

Source: Elaborated by the author.

Table 2 - Absolute and relative frequency of religiosity variables. São Paulo, 2015

\begin{tabular}{|c|c|c|c|}
\hline Variables & Category & $\mathbf{N}$ & $\%$ \\
\hline \multirow[t]{5}{*}{ ORA $(n=29)$} & More than 1 time per week & 1 & 3 \\
\hline & 1 per week & 18 & 62 \\
\hline & 2 to 3 times per week & 6 & 21 \\
\hline & Sometimes per week & 3 & 10 \\
\hline & Never & 1 & 3 \\
\hline \multirow[t]{5}{*}{ NORA $(n=29)$} & More than 1 day & 4 & 14 \\
\hline & Daily & 13 & 45 \\
\hline & 2 or + per week & 7 & 24 \\
\hline & Few times per month & 3 & 10 \\
\hline & Rarely or never & 2 & 7 \\
\hline \multirow[t]{3}{*}{ IR1 (n=29) } & Totally true for me & 23 & 79 \\
\hline & True in general & 5 & 17 \\
\hline & I am not right & 1 & 3 \\
\hline \multirow[t]{2}{*}{ IR2 (n=29) } & Totally true for me & 17 & 59 \\
\hline & True in general & 12 & 41 \\
\hline \multirow[t]{3}{*}{ IR3 (n=29) } & Totally true for me & 12 & 41 \\
\hline & True in general & 16 & 55 \\
\hline & I am not right & 1 & 3 \\
\hline
\end{tabular}

Source: Elaborated by the author.

Legend: $\mathbf{O R A}=$ Organizational Religious Affiliation, $\mathbf{N O R A}=$ Non Organizational Religious Affiliation; IR1= Feeling the presence of God or the Holy Spirit; IR2= my beliefs are my way of life; IR3=I strive to live my religion in all aspects of life.

Table 3 - Descriptive analysis of the dimensions of the Fantastic and total score. São Paulo, 2015

\begin{tabular}{lccccc}
\hline $\begin{array}{l}\text { Variable/ } \\
\text { Dimensions }\end{array}$ & Average & Median & $\begin{array}{c}\text { Standard } \\
\text { Deviation }\end{array}$ & Minimum & Maximum \\
\hline Family/Friends & 7.10 & 7 & 0.98 & 5 & 8 \\
Activities & 2.93 & 2 & 2.16 & 0 & 8 \\
\hline
\end{tabular}

to be continued... 


\begin{tabular}{llcccc}
\hline Nutrition & 7.79 & 8 & 2.45 & 1 & 12 \\
Cigar/Drugs & 15.07 & 15 & 1.16 & 12 & 16 \\
Alcohol & 11.89 & 12 & 0.31 & 11 & 12 \\
Sleep/Stress/Sex & 16.82 & 17 & 2.02 & 14 & 20 \\
Type of Behavior & 4.79 & 5 & 1.50 & 1 & 8 \\
Insight & 9.21 & 9 & 1.97 & 3 & 12 \\
Work & 3.24 & 3 & 0.74 & 2 & 4 \\
TOTAL FANTASTIC & 79.42 & 78.5 & 7.18 & 65 & 94 \\
\hline
\end{tabular}

Source: Elaborated by the author.

Table 4 - Average, median and Mann-Whitney test to compare the dimensions of religiosity and the variable category "practicing or not." São Paulo, 2015.

\begin{tabular}{|c|c|c|c|c|c|}
\hline \multirow[t]{3}{*}{ Variable } & \multicolumn{4}{|c|}{ Practicing } & \multirow[t]{3}{*}{ p-valor } \\
\hline & \multicolumn{2}{|c|}{ Yes } & \multicolumn{2}{|c|}{ No } & \\
\hline & Average & Median & Average & Median & \\
\hline ORA & 2.28 & 2 & 4.0 & 4 & 0.0229 \\
\hline NORA & 2.36 & 2 & 3.5 & 4 & 0.0928 \\
\hline IR1 & 1.24 & 1 & 1.3 & 1 & 0.8939 \\
\hline IR2 & 1.36 & 1 & 1.8 & 2 & 0.1702 \\
\hline IR3 & 1.60 & 2 & 1.8 & 2 & 0.5912 \\
\hline
\end{tabular}

Source: Elaborated by the author.

Legend: ORA= Organizational Religious Affiliation, NORA= Non Organizational Religious Affiliation; IR1= Feeling the presence of God or the Holy Spirit; IR2= my beliefs are my way of life; IR3= I strive to live my religion in all aspects of life.

Table 5 - Spearman correlation between the religious dimension and the Fantastic dimensions. São Paulo, 2015.

\begin{tabular}{lllllll}
\hline Fantastic dimensions & cetegories & ORA & NORA & IR1 & IR2 & IR3 \\
FAMILY & $\mathrm{R}$ & -0.01 & -0.10 & 0.04 & 0.11 & 0.04 \\
ANDD FRIENDS & $\mathrm{p}$-valor & 0.9482 & 0.5899 & 0.8227 & 0.5746 & 0.8410 \\
\multirow{2}{*}{ ACTIVITIES } & $\mathrm{R}$ & -0.17 & -0.18 & 0.10 & 0.11 & 0.21 \\
& $\mathrm{p}$-valor & 0.3914 & 0.3534 & 0.6021 & 0.5805 & 0.2768 \\
\hline \multirow{2}{*}{ NUTRITION } & $\mathrm{R}$ & -0.19 & -0.04 & -0.30 & -0.13 & -0.12 \\
& $\mathrm{p}$-valor & 0.3416 & 0.8261 & 0.1267 & 0.5200 & 0.5483 \\
\multirow{2}{*}{ CIGAR DRUGS } & $\mathrm{R}$ & -0.23 & 0.03 & -0.01 & -0.03 & -0.01 \\
& $\mathrm{p}$-valor & 0.2307 & 0.8667 & 0.9441 & 0.8887 & 0.9423 \\
\hline \multirow{2}{*}{ ALCOHOL } & $\mathrm{R}$ & -0.23 & 0.02 & -0.09 & 0.07 & -0.25 \\
& $\mathrm{p}$-valor & 0.2418 & 0.9389 & 0.6485 & 0.7361 & 0.2051 \\
\multirow{2}{*}{ SLEEP STRESS SEX } & $\mathrm{R}$ & -0.32 & -0.35 & -0.15 & -0.31 & -0.05 \\
& $\mathrm{p}$-valor & 0.1020 & 0.0688 & 0.4517 & 0.1120 & 0.8091 \\
\hline
\end{tabular}

to be continued... 


\begin{tabular}{lllllll}
\hline \multirow{2}{*}{ BEHAVIOR } & $\mathrm{R}$ & 0.04 & -0.15 & 0.14 & 0.26 & 0.25 \\
& $\mathrm{p}$-valor & 0.8533 & 0.4255 & 0.4645 & 0.1809 & 0.1900 \\
\hline \multirow{2}{*}{ INSIGHT } & $\mathrm{R}$ & 0.22 & 0.05 & 0.11 & 0.04 & -0.09 \\
& $\mathrm{p}$-valor & 0.2556 & 0.8055 & 0.5663 & 0.8525 & 0.6571 \\
\hline \multirow{2}{*}{ WORK } & $\mathrm{R}$ & 0.04 & 0.11 & 0.06 & -0.21 & -0.30 \\
& $\mathrm{p}$-valor & 0.8444 & 0.5765 & 0.7537 & 0.2783 & 0.1082 \\
\hline \multirow{2}{*}{ TOTAL FANTASTIC } & $\mathrm{R}$ & -0.25 & -0.10 & 0.05 & 0.06 & 0.01 \\
& $\mathrm{p}$-valor & 0.2206 & 0.6416 & 0.8035 & 0.7617 & 0.9471 \\
\hline
\end{tabular}

Source: Elaborated by the author.

Legend: ORA= Organizational Religious Affiliation, NORA= Non Organizational Religious Affiliation; IR1= Feeling the presence of God or the Holy Spirit; IR2= my beliefs are my way of life; IR3=I strive to live my religion in all aspects of life.

\section{DISCUSSION}

The study was conducted on a regional FHS of a district of the southern area of São Paulo, with a significant predominance of Evangelicals (79\%; $n=23)$. It may have influenced the result that shows representative as those who devote their time to individual religious activities (86\%; $n=25$ ).

Of the 29 professionals surveyed, 59\% $(n=17)$ reported receiving spirituality approach on customer service in their education, supporting the standard promulgated in 2009 by the Ministry of Health together with the Ministry of Education, releasing a document format guideline entitled National Program of Vocational Training Reorientation Health - PROHEALTH (p.46, 58) ${ }^{19}$.

This program was established in the academic environment, specifically in health and to improve the training of nurses and doctors. They would have the responsibility in the exercise of their professional role by promoting healthy lifestyles and reconciling the needs of their patients with their community. Thus, these professionals would then act as social change agent ${ }^{19}$.

It is believed that the promotion of healthy lifestyles should happen through a comprehensive action, as proposed by the SUS, or the doctor, nurse or any professional acting in health must consider that the man is integral and should be assisted with this comprehensive vision for a health system that also seeks the integrality 9 .

In this sense, authors suggest that health professionals need to consider the patient as a biopsychosocial being and that religion can contribute to clinical practice, pointing out that, if it is really considered by these professionals, better results will be felt in Brazilian society ${ }^{20,21}$.

Among the participants of this study, $65 \%$ $(n=19)$ attended their religious services "once or more per week" and 59\% $(n=17)$ had their prayers, Bible reading and meditation "daily or more than once per day". Comparing this study with the results of research conducted with 82 elderly enrolled in the FHS in Bahia, it was observed that $57 \%(n=70)$ of them attended their religious services, and $79.3 \% \quad(n=65)$ performed their practices in private ${ }^{22}$.

It was observed that in Intrinsic Religiosity (IR) in the categories "totally true for me" and "true in general", there were more than 97\% $(n=28)$ of participants in this group, in all dimensions, indicating that they consider religiosity as very important, that the presence of God in the life and beliefs are behind all the way to live and who strive to live the religion in all aspects of life.

In our country specifically, the subject R/S permeates our very significantly society, as it is manifested as an intrinsic element to an absolute parity of the Brazilian people, which 
can be confirmed by the study of 3007 people ( $n=2346$ adults $n=661$ adolescents) which had a representation of 143 cities. Of them, 95\% of respondents reported having a religion, and $83 \%$ considered religion as very important ${ }^{23}$.

The demographics laboratory and population studies of the Federal University of Juiz de Fora based on the IBGE reported on the 2010 Census microdata referring to the religion - shows results in which the census confirms that there is a strong trend towards greater religious plurality in the country. According to what is stated, Catholics had a participation rate of about $90 \%$ until 1980, that fell to $73.6 \%$ in 2000 and $64.6 \%$ in 2010. On the other hand, evangelicals had a rate of $5.2 \%$ in 1970 , and fell to $15.4 \%$ in 2000 and reached $22.2 \%$ in 2010 . The people who declared no religion were only $0.8 \%$ in 1970 , becoming to $7.4 \%$ in 2000 and reached $8 \%$ in 2010. The other religions have gone from $2.3 \%$ in 1970 to $3.7 \%$ in 2000 and $5.2 \%$ in 2010 . Therefore, in the aspect of religious affiliations, the country is becoming more heterogeneous and more plural. However, this does not diminish the strength of the $\mathrm{R} / \mathrm{S}$ existing in our country, but the search clears the existing large dominance in this area of our society ${ }^{23}$.

The nine questionnaire dimensions of the Fantastic Lifestyle analyzed in the present study were a rating of $3.8 \%$ good $(n=1), 76.9 \%$ very good $(n=20)$ and $19.2 \%$ excellent $(n=5)$. This result is presented better than another similar study, in which the same questionnaire was applied to 206 people in a shopping mall in the southern area of São Paulo, and $11.7 \%(n=15)$ had a "regular" lifestyle 26.6\% (n=34) "good", $48.4 \%(n=62)$ "very good" and $12.5 \quad(n=16)$ "excellent" ${ }^{\prime \prime}$.

It was also observed in this study that the Fantastic total score reached an average of 79.4 $(\mathrm{SD}=7.18)$, classified as "very good"; but the dimension "activities" was below the average $(2.93 \%$, on a scale of $0-8)$. Other studies have also shown these results that physical activity has been a neglected dimension(7). However, there is a firm belief that $R / S$ could be a motivating factor for the commitment of this dimension ${ }^{24}$.

In the analysis of the correlation between $\mathrm{R} / \mathrm{S}$ and Lifestyle, there were no statistically significant associations, except Mann-Whitney test between Organizational Religious Affiliation
(ORA) and "practicing or not," meaning that professionals who attend their religious services they were also "practitioners" of their faith.

Understanding about "being a practitioner or not," the person cannot simply make a theoretical statement that belongs to a particular religion and this statement does not have any practical or tangible corresponding in their day to day. It is understood that anyone who claims to be a practicing person of a religion/faith also develops directions and meanings established by this faith in their life, occurring regular practices that guide the every day of the person, because every action practiced makes sense to whom it carries, gaining meaning in their decisions, whether personal or professional ${ }^{21}$.

In this study, there are two limitations objectively: a small sample and need for greater variability in types of religion. It was found that the evangelical population faith is predominant in which the data were collected. It is believed to be necessary to carry out further research more informed data diversified which represent a broad vision and a greater diversity of those suggested and presented here.

\section{CONCLUSION}

The professionals who work in the research of the regional NASF were characterized by women, evangelical, practicing their religion. Among these professionals, most reported having received spiritual approach and religiosity in their academic training.

It was observed in the research that the DUKE - DUREL Religiosity Index participants are people involved in their religious services, as most said practicing their religion and consider it of great importance in their daily life, personal and professional.

As for the lifestyle, through the questionnaire Fantastic Lifestyle, it was obtained a rating of "very good", for a total score that averaged 79.4 (SD=7.18), however, these professionals showed deficits in the dimension "physical activity", whose average measured was below the expected standard. 
The correlation between R/S and Lifestyle statistically significant associations were not found. However, statistically, significant associations were found between the variables of dimension Organizational Religious
Affiliation (attendance at religious services) and "practicing or not" the religion, meaning that those who attended more religious services were also those who were "practitioners" of their faith.

1. Miller L, Bansal R, Wickramaratne P, Hao X, Tenke CE, Weissman MM et al. Neuroanatomical Correlates of Religiosity and Spirituality: a Study in Adults at High and Low Familial Risk for Depression. Jama Psychiatry. 2014;71(2):128-35.

2. Koenig HG, Berk LS, Daher N, Pearce MJ, Belinger D, Robins CJ et al. Religious involvement, depressive symptoms, and positive emotions in the setting of chronic medical illness and major depression. J Psych Research. 2014;77(2):135-43.

3. Silva OEM, Abdala GA, Silva IA, Meira MDD. Spiritual Care in Nursing Practice: nurses's perception. J Nursing UFPE on line. 2015;9(8):8817-23.

4. Abdala GA, Kimura M, Duarte YAO, Lebrão ML, Santos B. Religiosidade e Qualidade de Vida Relacionada à Saúde do Idoso. Rev Saúde Pública. 2015;49(55):1-9.

5. Cres MR, Abdala GA, Meira MDD, Teixeira CA, Ninanhuaman MFML, Moraes MCL. Religiosidade e estilo de vida de uma população adulta. Rev Bras Prom Saúde. 2015:28(2):1-10.

6. Nahas MV, Barros MV, Francalacci V. O pentáculo do bem-estar, base conceitual para avaliação do estilo de vida de indivíduos ou grupos. Rev Bras Ativ Fís Saúde. 2012;5(2):48-59.

7. Santos ARM, Dabbicco P, Cartaxo HGO, Silva EAPC, Souza MRM, Freitas CMSM. Revisão Sistemática Acerca da Influência da Religiosidade na Adoção de Estilo de Vida ativo. Rev Bras Prom Saúde. 2013;26(3):419-25.

8. Silva LHP, Penha RM, Silva MJP. Relação entre crenças espirituais/Religiosas e Bem-Estar espiritual da equipe de enfermagem - Rev REME. 2012;13(3):677-85.

9. Brasil. Ministério da Saúde. Secretaria Nacional de Assistência à Saúde - ABC DO SUS - Doutrinas e princípios. Brasília. 1990; 4-5. 10. Goulart BNG, Chiari BM. Humanização das práticas do profissional de saúde: contribuições para reflexão. Ciência \& Saúde Coletiva. 2010;15(1):255-68.

11. Leite TRA, Santos BRM. Pressão Arterial e Estilo de Vida de Estudantes Universitários. Rev Bras Ciências Saúde 2011;9(27):14-20. 12. OMS. ORGANIZAÇÃO MUNDIAL DA SAÚDE (OMS). Organização Pan-Americana da Saúde (OPAS) - Doenças Crônicas degenerativas e obesidade: Estratégia Mundial sobre alimentação saudável, atividade física e saúde. Pág. 07. 2003. Disponível em: <http://www.maeterra.com.br/site/biblioteca/Obesidade-OPAS.pdfm>.

13. Brasil. Ministério da Saúde - (ANS). Agência Nacional de Saúde Suplementar. Artigo. 3. Pág. 30. Brasilia. 2009.

14. Brasil. Agência Nacional de Saúde Suplementar. Promoção da Saúde e Prevenção de riscos e doenças na saúde suplementar brasileira: resultados do laboratório de inovação. Brasília, p. 39, 2013.

15. Tomasso CS, Beltrame IL, Lucchetti G. Knowledge and attitudes of nursing professors and students concerning the interface between spirituality, religiosity and health. Rev Latino-Am Enferm. 2011;19(5):1205-13.

16. Taunay TCD, Gondim FAA, Macêdo DS, Moreira-Almeida A, Gurgel LA, Andrade LMS et al. Validação da versão Brasileira da Escala de Religiosidade de Duke (DUREL). Rev Psiquiat Clínica. 2012;39(4):130-5.

17. Lucchetti G, Lucchetti ALG, Peres MF, Leão FC, Moreira-Almeida A, Koenig HG. Validation of the Duke Religion Index: DUREL (Portuguese Version). J Relig Health. 2012;51(2):579-86.

18. Silva AMM, Brito IS, Amado JMC. Tradução, adaptação e validação do questionário Fantastic Lifestyle Assessment em estudantes do ensino superior. Cienc Saúde coletiva. 2014;19(6):1901-10.

19. Brasil. Ministério da Saúde e Ministério da Educação. Programa Nacional de Reorientação da Formação Profissional em Saúde PRÓ-SAÚDE Brasília. 2005;46,58.

20. Ferreira FLS. A Influência da Religiosidade na Saúde Mental: Uma Revisão Bibliográfica. 2014. Monografia (Bacharelado em Saúde Coletiva). Universidade de Brasilia. 2014.

21. Alves JS, Junges JR, López LC. A dimensão religiosa dos usuários na prática do atendimento à saúde: percepção dos profissionais da saúde. O Mundo da Saúde. 2010;34(4):430-6.

22. Santos NC, Abdala GA. Religiosidade e qualidade de vida relacionada à saúde dos idosos em um município na Bahia, Brasil. Rev Bras Geriatr Gerontol. Rio de Janeiro. 2014;17(4):795-805.

23. Moreira-Almeida A, Pinsky I, Zaleski M, Laranjeira R. Envolvimento Religioso e Fatores Sociodemográficos: resultados de um levantamento nacional no Brasil. Rev Psiq Clín. 2010;37(1):12-5.

24. Costa VV, Silva KCS. Melhoria na qualidade de vida em idosos por meio de atividades físicas: uma revisão bibliográfica. Rev EFDeportes. 2014;19(193):1. 